\title{
Klinefelter syndrome and germ cell tumors: review of the literature
}

Kimberley Bonouvrie ${ }^{1,2}$ D , Jutte van der Werff ten Bosch ${ }^{2,3}$ and Machiel van den Akker ${ }^{2,3^{*}}$

\begin{abstract}
Objective: The most common presentation of Klinefelter syndrome (KS) is infertility and features of hypogonadism. Currently no consensus exists on the risk of malignancy in this syndrome. Several case reports show an incidence of extragonadal germ cells tumors (eGCT) of 1.5 per 1000 KS patients (OR 50 against healthy population). Malignant germ cell tumors are rare in children. They account for $3 \%$ of all children cancers. Young patients with a germ cell tumor are not routinely tested for Klinefelter syndrome. This can therefore result in underdiagnosing. Literature data suggest a correlation between eGCT and KS. To the best of our knowledge there is no precise description of the primary locations of germ cell tumors in KS patients. The purpose of this study is to evaluate age groups and primary locations of extragonadal germ cell tumors in Klinefelter patients. With this data we investigate whether it is necessary to perform a cytogenetic analysis for KS in every eGCT patient.

Study design: This study is based on case report publications in PubMed/Medline published until march 2020 that described "Klinefelter Syndrome (MeSH) AND/OR extragonadal germ cell tumors". Publications were included when patients age, location and histology of the germ cell tumor was known. Two double blinded reviewers selected the studies.Results: 141 KS patients with eGCTs were identified. Mean age at presentation was 17.3 years (StDev + 10.2). In contrast to the extragonadal germ cell tumors in adults, most eGCT in children were mediastinal or in the central nervous system (respectively 90/141; 64\% and 23/141; 16\% of all tumors). Distribution of histologic subtypes showed that the largest fraction represented a teratoma, mixed-type-non-seminomateus GCT and germinoma, respectively $34 / 141 ; 24 \%, 26 / 141 ; 18 \%$ and $20 / 141 ; 14 \%$ of all tumors.

Conclusion: These data suggest a correlation between primary extragonadal germ cell tumors and Klinefelter syndrome. There appears to be an indication for screening on KS in young patients with an eGCT in the mediastinum. A low threshold for radiologic examinations should be considered to discover eGCT. We emphasize the need for genetic analysis in all cases of a male with a mediastinal germ cell tumor for the underdiagnosed Klinefelter syndrome.
\end{abstract}

Keywords: Klinefelter syndrome, Extragonadal germ cell tumor malignancy, Incidence analysis

\footnotetext{
* Correspondence: machielvdakker@gmail.com

${ }^{2}$ Department of Pediatrics, ZNA Queen Paola Children's Hospital, Lindendreef 1, 2020 Antwerp, Belgium

${ }^{3}$ Department of Pediatric Hematology and Oncology, University Hospital Brussel, Brussels, Belgium

Full list of author information is available at the end of the article
}

(C) The Author(s). 2020 Open Access This article is licensed under a Creative Commons Attribution 4.0 International License, which permits use, sharing, adaptation, distribution and reproduction in any medium or format, as long as you give appropriate credit to the original author(s) and the source, provide a link to the Creative Commons licence, and indicate if changes were made. The images or other third party material in this article are included in the article's Creative Commons licence, unless indicated otherwise in a credit line to the material. If material is not included in the article's Creative Commons licence and your intended use is not permitted by statutory regulation or exceeds the permitted use, you will need to obtain permission directly from the copyright holder. To view a copy of this licence, visit http://creativecommons.org/licenses/by/4.0/. The Creative Commons Public Domain Dedication waiver (http://creativecommons.org/publicdomain/zero/1.0/) applies to the data made available in this article, unless otherwise stated in a credit line to the data. 


\section{Introduction}

Klinefelter syndrome (KS) is characterized by hypogonadism, gynecomastia, infertility and the addition of at least one extra $\mathrm{X}$ chromosome to the standard human male karyotype (most frequently 47,XXY) [1]. KS is usually acquired through a non-disjunction during parental gametogenesis of either paternal (53\%) or maternal (44\%) origin [2]. The greater the number of extra $\mathrm{X}$ chromosomes (47 XXY or a mosaicism), the greater the phenotypic consequences, both gonadal and extragonadal [3]. KS is the most common sex chromosome disorder, occurring in about one out of 600 males [4]. Tough only approximately one fourth of adult males with KS are diagnosed [5]. KS has been associated with conditions like venous disease, auto-immune disorders, mild neurobehavioral deficit, diabetes mellitus, sexual precocity and osteoporosis [6]. KS patients have an increased risk of several malignancies, especially male breast cancer [7, 8] and extragonadal germ cell tumors, primarily localized in the mediastinum. Male breast cancer has been most highly associated with the $47 \mathrm{XXY}$ mosaics, suggesting up to 20-30 times greater incidence in patients with $\mathrm{KS}$ compared to patients with normal karyotype [7, 8].

Different neoplasms such as testis, lymphoreticular malignancies may occur in $1-2 \%$ of the cases with $\mathrm{KS}$. Hematological malignancies, such as leukemia and lymphoma have been described as well [9].

$\mathrm{KS}$ has been described earlier in correlation with an increased risk of developing extragonadal germ cell tumors, though routine screening in the $\mathrm{KS}$ population is not standard of care [10]. The most common primary site for an extragonadal germ cell tumor (eGCT) is the mediastinum, followed by the peritoneum [11]. GCTs are tumors originating from the germ cells, the precursors of the sperm and ova, and have the potential to produce all of the somatic (embryonic) and supporting (extraembryonic) structures of a developing embryo. They account only for $3.4 \%$ of all pediatric malignancies [12]. Germ cell tumors are the most common malignancy of the testicle, with a peak incidence in males between 15 and 35 years old. It is known that about $5 \%$ of the germ cell tumors are extragonadal [13]. A large number of eGCT have been described in association with $\mathrm{KS}$, most often located in the mediastinum with a relative risk of at least 50 [14]. There are different risk factors available in literature. Williams et al. describe that approximately one-third of males with mediastinal germ cell tumors have Klinefelter syndrome [15], while others describe only $8 \%$ of male patients with primary mediastinal GCT have KS [14]. The overall incidence of cancer in men with $\mathrm{KS}$ seems to be similar to that of the general population but some malignancies show a significantly higher prevalence. Although data in the literature on cancer prevalence in $\mathrm{KS}$ are abundant, most of them are individual case reports. By reviewing all cases of $\mathrm{KS}$ and GCT reported in the medical case reports, we show the relationship between KS and eGCT, and thereby emphasizing the need for genetic analysis in all cases of a male with a mediastinal GCT for the underdiagnosed $\mathrm{KS}$.

\section{Methods}

PubMed/Medline search was conducted in the Englishlanguage literature using the keywords "Klinefelter Syndrome $(\mathrm{MeSH})$ AND/OR extragonadal germ cell tumors". The literature was reviewed from 1967 until march 2020 on eGCT associated with Klinefelter syndrome. All patients with KS and an eGCT were documented by author of the paper, year of publication, location of primary tumor, age of the patient and histology of the tumor. The locations of the germ cells tumors were divided into; mediastinum, central nervous system, testis and abdomen. The major morphologic categories are embryonal carcinoma, germinoma, teratoma, endodermal sinus tumor (yolk sac), choriocarcinoma and gonadoblastoma. Teratocarcinoma refers to a germ cell tumor that is a mixture of teratoma with embryonal carcinoma or choriocarcinoma, or with both. When not further specified, cases are classified under mixed GCT of unknown origin.

\section{Results}

A total of 196 papers were reviewed and 147 of patients with KS and a GCT identified. Two patients presented with a double tumor and were excluded in further analysis: a patient with both testis and mediastinum tumor and an 8-year-old patient with a hypophyseal stalk and mediastinum tumor. Of 145 patients 4 persons had unknown ages and were excluded for further analysis. A total 141 patients were included in this analysis.

\section{Articles published per year}

Articles that were included were published from 1972 until march 2020. From 1971 until 1986 only several reports were written (total of 38 patients). Most patients found in case reports (total 72 patients; $51 \%$ ) were published between 1987 and 2006. Since 200630 patients with KS and GCS were published in several case series.

\section{Age of the patients}

Mean age was 17.3 years (StDev +-10.2$)$. Thirty percent (42 cases) of the reported cases were in the age-group of 15-19 years old. Of 141 patients, 54 patients were below the age of 14 (prepubertal), as 87 patients were postpubertal with the oldest age of 64 years. The incidence of germ cell tumors by age group are represented in Fig. 1. 


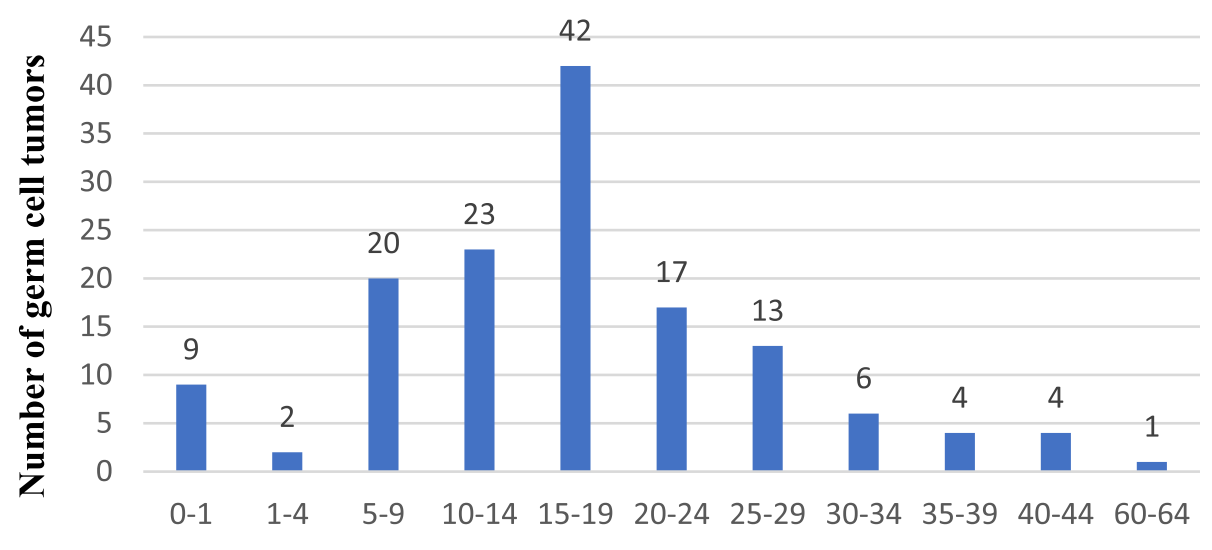

Age of patients in years

Fig. 1 Germ cell tumor incidence in Klinefelter syndrome by age group $(n=141)$

\section{Localization of the tumor}

The most frequent location of the germ cell tumors appeared to be the mediastinum $(n=90)$, followed by the central nervous system $(n=23)$, testis $(n=15)$ and abdomen $(n=13)$ (Table 1$)$. Especially in age $5-19$ years the mediastinal germ cell tumors comprise the largest fraction (Fig. 2). Children under the age of 5 show more intra-abdominal localizations $(n=6)$. The central nervous system seems to be more involved at postpubertal age (15-29 years old).

\section{Histology of the tumor}

Distribution of histologic subtypes showed that the largest fraction represented a teratoma, mixed-type-nonseminomateus GCT and germinoma, respectively 34/ $141 ; 24 \%, 26 / 141 ; 18 \%$ and $20 / 141 ; 14 \%$ of all tumors. Figure 3 show the prepubertal Klinefelter patients were the largest fractions of mediastinal germ cell tumors comprise teratomas $(n=19)$, mostly found in age $0-1$ years $(n=9)$ and 5-9 $(n=7)$. Secondly 11 nonseminomatous GCT were found in prepubertal patients, most in age 10-14 $(n=8)$. Thirdly, eight mixed germ cell tumors were found, mostly in age $5-9$ years $(n=4)$ and $10-14$ years $(n=3)$. Between the ages of $5-9$ years old there is a mix of teratomas, mixed GCTs and mixed non seminomatous GCT. In age group 10-14 the mixed

Table 1 Localization of extragonadal germ cell tumors of 141 Klinefelter syndrome patients. Most germ cell tumors were found in the mediastinum, followed by the central nervous system

\begin{tabular}{lll}
\hline & Total patients $(\mathrm{n})$ & \% patients \\
\hline Mediastinum & 90 & 64 \\
Cental Nervous system & 23 & 16 \\
Testis & 15 & 11 \\
Abdomen & 13 & 9 \\
Total & 141 & \\
\hline
\end{tabular}

non-seminomateus GCT's with germinomas and mixed GCTs are the most frequent. In the largest group of 1519 years of age there is a mix of mixed nonseminomatous GCT, teratomas, malignant GCT, germinomas and yolk sac tumors. From the 87 postpubertal patients the largest fractions of mediastinal germ cell tumors comprise germinoma $(n=15)$, teratoma $(n=15)$ and mixed non-seminomatous GCT $(n=15)$ all most found in age 15-19 years (Fig. 4).

\section{Discussion Etiology}

Tumors of germ cell origin occur with increased frequency in disorders of sexual differentiation, including cryptorchidism, XY dysgonadal dysgenesis, testicular feminization syndrome and KS. The overall incidence of cancer in men with KS is similar to that of the general population, but some malignancies show a significantly higher prevalence in these patients. The reported incidence of eGCT in KS patients is 1.5/1.000, a fifty-fold increase over the general population [16]. Although it has been estimated that $1-2 \%$ of KS patients develop a neoplasm, previous data demonstrated that young males with KS have a relative risk of around 66.7 for developing extra-gonadal germ cell tumors $[17,18]$. Several reports describe the association between KS and GCT, although the cause of this association is unknown. Some postulate that the hypergonadotropism due to the gonadal insufficiency promote germ cell proliferation, while others hypothesize the assignment of a GCT susceptibility gene to the X chromosome [19]. In KS is the mediastinum the most prevalent site compared to the gonads in those with KS. Until now the altered hormones, such as elevated estrogen-to-testosterone ratio and elevated gonadotropin level have been the focus for explaining the observed increase in male breast cancer and extragonadal germ cell tumors among Klinefelter 


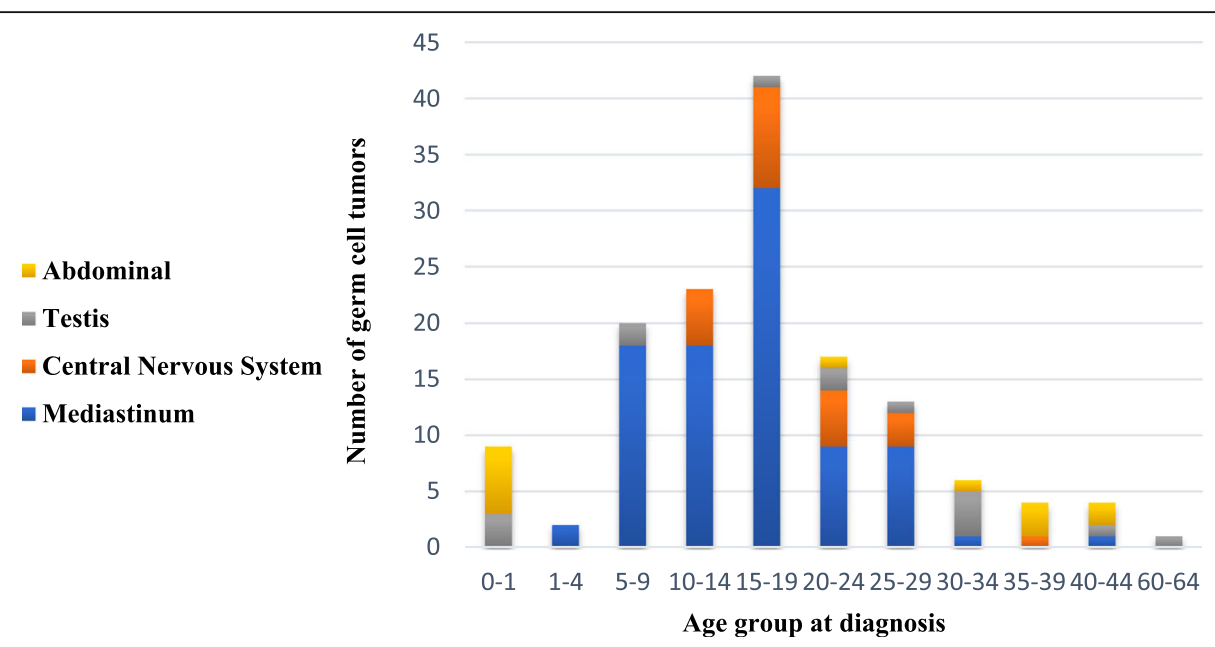

Fig. 2 Germ cell tumor indicence by location and age group. Most germ cell tumors in klinefelter patients were diagnosed were reported between the age of 15-19years. The mediastinum is the most common location in age group 5-29years

syndrome patients $[7,20]$. The abnormal hormonal influence could also increase the malignant potential [10].

\section{Localization and age}

GCTs originate from primitive germ cells, which migrate during the embryogenesis from their origin in the endoderm in the yolk sac along the urogenital ridge to the gonads. Abnormal migration causes the germ cells to be distributed, to the gonads and to extragonadal localizations. In the normal course of development these cells die off, but if they are persistent or misplaced, they may give rise to germ cell tumors. This may be the result of an abnormality in the primordial germ cell itself or in its micro-environment [21]. Furthermore, there is a hypothesis that the germ cells transformed in the testis have a reserve migration pathway [22]. This hypothesis is supported by the fact that testicular GCTs and ECTGs share the common cell of origin [23, 24]. Germ cell tumors are classified as extragonadal if there is no evidence of a primary tumor in the testis [25]. By unknown factors, dislocated germ cells undergo malignant transformation and to give rise to GCTs in extragonadal localizations. Germ cell tumors arise in both gonadal and extragonadal sites. In adults, $90 \%$ of primary germ cell tumors involve the testis or ovary, but it is known that in the pre-pubertal years there is a preference for extragonadal

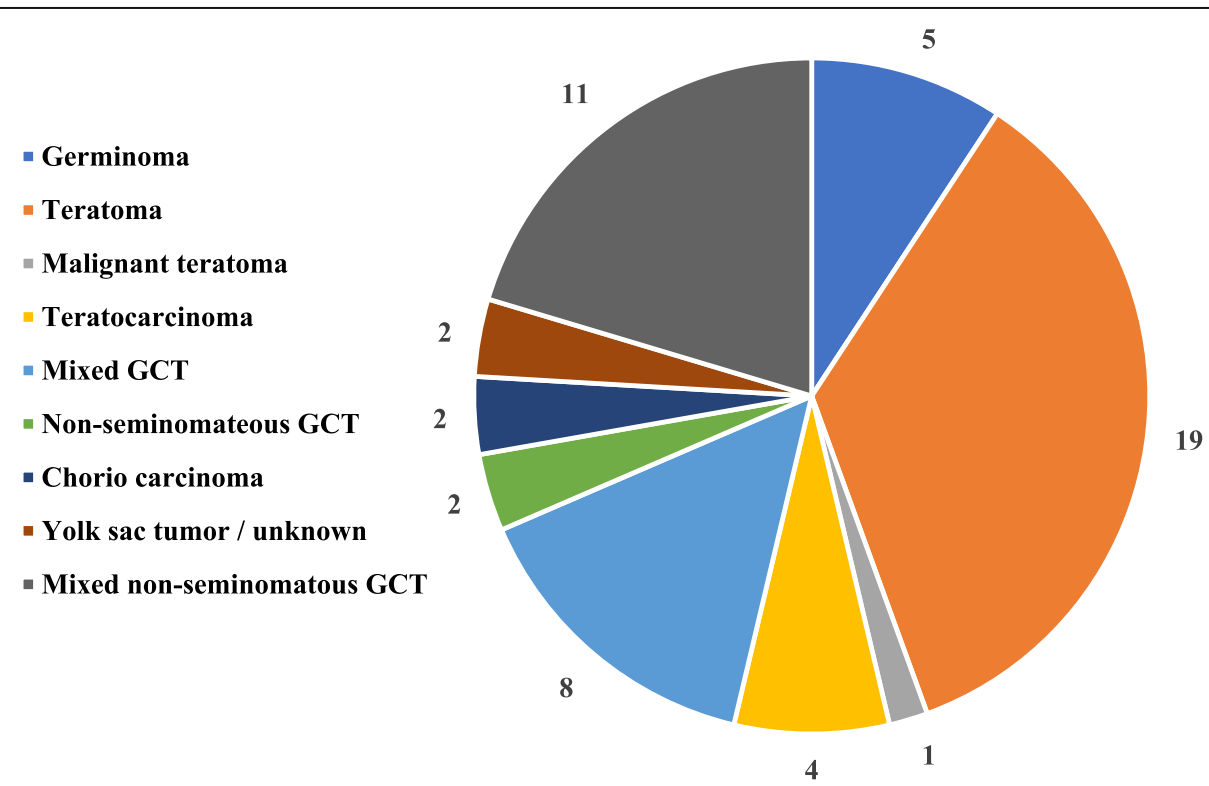

Fig. 3 Germ cell tumors in prepubertal patients ( $n=54$, age $0-14$ years). Most common germ cell tumors below the age of 14 years found is a teratoma, followed by an mixed non-seminomatous germ cell tumor. * GCT = germ cell tumor 


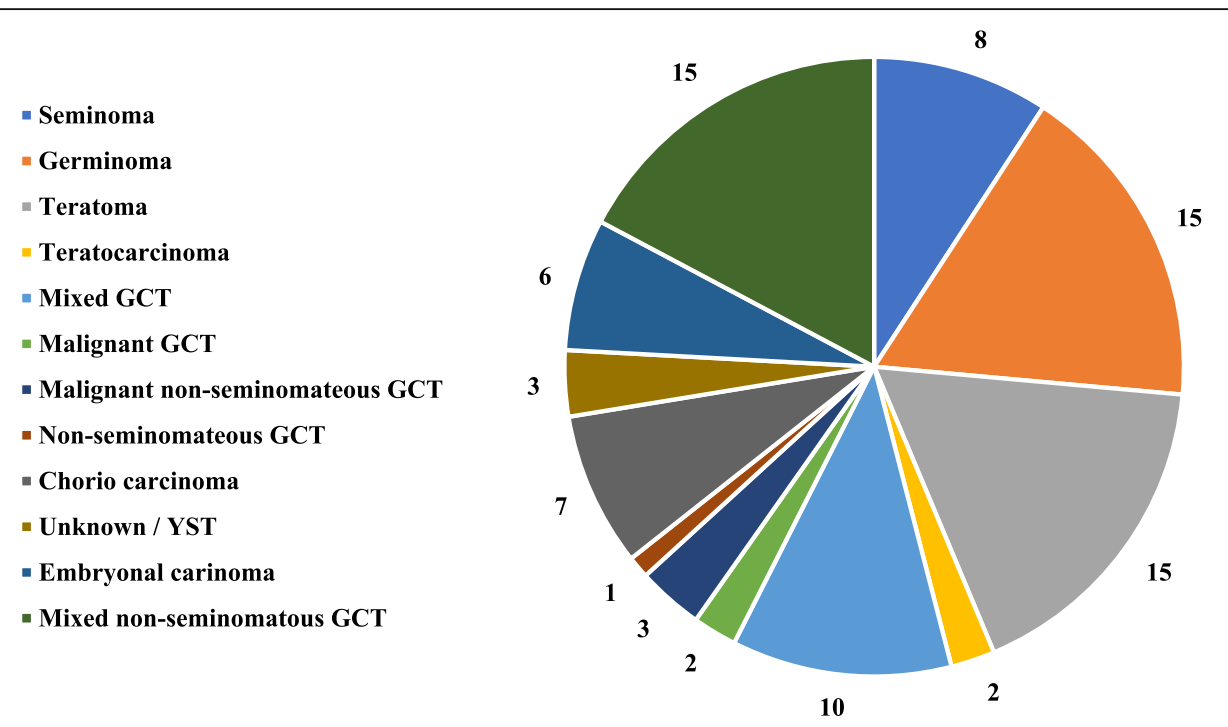

Fig. 4 Germ cell tumors in postpubertal patients ( $n=87$, age 15-64 years). Most common germ cell tumors above the age of 15 years found is a teratoma, germinoma and an mixed non-seminomatous germ cell tumor. ${ }^{*} \mathrm{GCT}=$ germ cell tumor. ${ }^{*}$ YST = yolc sac tumor

sites [26]. It is known that most primary eGCTs are found in midline structures (pineal region (6\%), mediastinum (7\%), retroperitoneum (4\%), sacrococcygeal region $(42 \%)$ or in the ovary $(24 \%)$, testis $(9 \%)$, and other sites (8\%) [27]. The anterior mediastinum is the third most common location for germ cell tumors in children. The mediastinum gives a generous space for expansion before the mass will cause symptoms, mediastinal germ cell tumors may achieve enormous size prior to detection. The patient's age at diagnosis appears to be a critical prognostic factor. EUROCARE data (European Cancer Registry based study on survival and care of cancer patient's project) stated that GCTs have an incidence of 31/1.000.000 people. Most GCTs arise in the gonads, with the highest incidence between age 25-40 years (testis) and 14-34 years (ovarian). eGCTs occur most frequently in the age-groups $0-4$ years and 15-34 years. It is assumed that the most common extragonal localizations in children are the central nervous system, followed by mediastinum/thorax and abdomen/pelvis. In our study more eGCTs were found in the mediastinum than in the central nervous system. The most common localization of a GCT in KS, is the mediastinum $(n=83)$ except for children under the age of 5 year in which the abdominal location is more frequent $(n=8)$. This is comparable with other known data. The GCTs are mostly located in the anterior mediastinum $[28,29]$.

In adults without KS, GCTs are mostly gonadal, whereas in children without KS, GCTs are mostly extragonadal (CNS responsible for the primarily location). Beresford et al. proposed that chest Rx should be performed as routine in young patients with KS [30]. The risk to develop a mediastinal GCT for children with KS is difficult to assess due to the rarity of mediastinal GCT and the underdiagnosed KS.

\section{Pathology}

Extragonadal germ cell tumors (eGCTs) represent 5$10 \%$ of all GCTs and most arise in the midline [31]. The most common midline sites are mediastinal, retroperitoneal, pineal gland and sacrococcygeal [32]. They can be divided into two histologic groups, germinoma and non-germinoma. For a tumor to be considered in one group, it must entirely consist of that single histology and cannot contain other GCT elements. The germinoma group is divided in germinoma (most often brain), dysgerminoma (ovary) and seminoma (testis), while the non-germinoma group is divided in teratoma (mature and immature), yolk sac tumor (endodermal sinus tumor), choriocarcinoma, embryonal carcinoma, gonadoblastoma and mixed GCTs. Seminomas may exist in a pure form, but any elevation of AFP indicates the presence of an element of a non-seminomatous tumor [33]. In addition, mediastinal germ cell tumors have a propensity to develop another malignancy (e.g., rhabdomyosarcoma, adenocarcinoma, permeative neuroectodermal tumor), which can become the predominant histology. Determination of serum tumor markers, $\beta$-HCG and AFP, is important in the diagnosis and follow-up of germ cell tumors. AFP and or beta-hCG is elevated in $85 \%$ of cases of extragonadal non-seminomatous GCTs [34] [35]. Elevations of $\beta$-HCG and AFP confirm a malignant component to the tumor. Yolk sac tumors produce AFP, while germinomas and choriocarcinomas, produce $\beta$-HCG. Benign teratomas may produce small elevation of the tumor markers. 


\section{Conclusion}

Our data suggest there is a strong correlation between primary germ cell tumors and Klinefelter syndrome. A higher prevalence of germ cell tumors in $\mathrm{KS}$ patients is seen in the mediastinum of young adults. We recommend that there is an indication to perform genetic analysis to confirm Klinefelter syndrome in young patients with an extragonadal germ cell tumor in the mediastinum.

Screening every patient with Klinefelter syndrome for early detection of germ cell tumors can be deliberated. Patients with Klinefelter syndrome should be closely monitored and provided with adequate information on the risk of malignancy.

\section{Supplementary information}

Supplementary information accompanies this paper at https://doi.org/10. 1186/s13633-020-00088-0.

Additional file 1.

\section{Abbreviations}

KS: Klinefelter Syndrome; eGCT: Extragonadal germ cell tumors; GCT: Germ cell tumors; CNS: Central nervous system; beta-hCG: Beta human chorionic gonadotropin; StDev: Standard deviation

\section{Acknowledgements}

Not applicable.

\section{Authors' contributions}

$\mathrm{KB}$ and MvdA contributed to the design and implementation of the review, to the analysis of the results and to the writing of the manuscript. JvdWtB contributed to the final version of the manuscript. All authors discussed the results and contributed to the final manuscript. The author(s) read and approved the final manuscript.

\section{Funding}

Not applicable.

\section{Availability of data and materials}

All data generated or analysed during this study are included in this published article and its supplementary information file.

\section{Ethics approval and consent to participate}

Not applicable.

\section{Consent for publication}

Not applicable.

\section{Competing interests}

The authors declare that they have no competing interests.

\section{Author details}

${ }^{1}$ Department of Pediatrics, Maxima Medisch Centrum, Veldhoven, The Netherlands. '2Department of Pediatrics, ZNA Queen Paola Children's Hospital, Lindendreef 1, 2020 Antwerp, Belgium. ${ }^{3}$ Department of Pediatric Hematology and Oncology, University Hospital Brussel, Brussels, Belgium.

Received: 22 April 2020 Accepted: 27 August 2020

Published online: 30 September 2020

\section{References}

1. Pradhan D, Kaman L, Dhillon J, Mohanty SK. Mediastinal mixed germ cell tumor in an infertile male with Klinefelter syndrome: a case report and literature review. J Cancer Res Ther. 2015;11(4):1034.
2. Volkl TM, Langer T, Aigner T, Greess H, Beck JD, Rauch AM, et al. Klinefelter syndrome and mediastinal germ cell tumors. Am J Med Genet A. 2006; 140(5):471-81.

3. McKenney JK, Heerema-McKenney A, Rouse RV. Extragonadal germ cell tumors: a review with emphasis on pathologic features, clinical prognostic variables, and differential diagnostic considerations. Adv Anat Pathol. 2007; 14(2):69-92.

4. Nielsen J, Wohlert M. Chromosome abnormalities found among 34,910 newborn children: results from a 13-year incidence study in Arhus, Denmark. Hum Genet. 1991;87(1):81-3.

5. Bojesen A, Juul S, Gravholt CH. Prenatal and postnatal prevalence of Klinefelter syndrome: a national registry study. J Clin Endocrinol Metab. 2003:88(2):622-6.

6. Aguirre D, Nieto K, Lazos M, Pena YR, Palma I, Kofman-Alfaro S, et al. Extragonadal germ cell tumors are often associated with Klinefelter syndrome. Hum Pathol. 2006;37(4):477-80.

7. Brinton LA. Breast cancer risk among patients with Klinefelter syndrome. Acta Paediatr. 2011;100(6):814-8.

8. Jackson AW, Muldal S, Ockey CH, O'Connor PJ. Carcinoma of male breast in association with the Klinefelter syndrome. Br Med J. 1965;1(5429):223-5.

9. Park YT, Park CH, Bae MA, Jung HS, Lee Yl, Lim JH, et al. Angioimmunoblastic T-cell lymphoma in a patient with Klinefelter syndrome. Am J Case Rep. 2016;17:529-34.

10. Nichols CR, Heerema NA, Palmer C, Loehrer PJ Sr, Williams SD, Einhorn LH Klinefelter's syndrome associated with mediastinal germ cell neoplasms. J Clin Oncol. 1987:5(8):1290-4.

11. Konheim JA, Israel JA, Delacroix SE. Klinefelter syndrome with poor risk Extragonadal germ cell tumor. Urol Case Rep. 2017;10:1-3.

12. Miller RW, Young JL Jr, Novakovic B. Childhood cancer. Cancer. 1995;75(1 Suppl):395-405.

13. Schmoll HJ. Extragonadal germ cell tumors. Ann Oncol. 2002;13(Suppl 4): 265-72.

14. Hasle $H$, Jacobsen BB, Asschenfeldt P, Andersen K. Mediastinal germ cell tumour associated with Klinefelter syndrome. A report of case and review of the literature. Eur J Pediatr. 1992;151(10):735-9.

15. Williams LA, Pankratz N, Lane J, Krailo M, Roesler M, Richardson M, et al. Klinefelter syndrome in males with germ cell tumors: a report from the Children's oncology group. Cancer. 2018:124(19):3900-8.

16. De Sanctis V, Fiscina B, Soliman A, Giovannini M, Yassin M. Klinefelter syndrome and cancer: from childhood to adulthood. Pediatr Endocrinol Rev. 2013;11(1):44-50.

17. Schneider DT, Lemburg P, Sprock I, Heying R, Gobel U, Nurnberger W. Introduction of the oncological pediatric risk of mortality score (O-PRISM) for ICU support following stem cell transplantation in children. Bone Marrow Transplant. 2000;25(10):1079-86.

18. Schneider DT, Schuster AE, Fritsch MK, Calaminus G, Gobel U, Harms D, et al. Genetic analysis of mediastinal nonseminomatous germ cell tumors in children and adolescents. Genes Chrom Cancer. 2002;34(1):115-25.

19. Rapley EA, Crockford GP, Teare D, Biggs P, Seal S, Barfoot R, et al. Localization to Xq27 of a susceptibility gene for testicular germ-cell tumours. Nat Genet. 2000;24(2):197-200.

20. Hasle H, Mellemgaard A, Nielsen J, Hansen J. Cancer incidence in men with Klinefelter syndrome. Br J Cancer. 1995:71(2):416-20.

21. Glenn OA, Barkovich AJ. Intracranial germ cell tumors: a comprehensive review of proposed embryologic derivation. Pediatr Neurosurg. 1996:24(5):242-51.

22. Chaganti RS, Houldsworth J. Genetics and biology of adult human male germ cell tumors. Cancer Res. 2000;60(6):1475-82.

23. Chaganti RS, Rodriguez E, Mathew S. Origin of adult male mediastinal germcell tumours. Lancet. 1994;343(8906):1130-2.

24. Hailemariam S, Engeler DS, Bannwart F, Amin MB. Primary mediastinal germ cell tumor with intratubular germ cell neoplasia of the testis--further support for germ cell origin of these tumors: a case report. Cancer. 1997; 79(5):1031-6.

25. Wick MRPE, Orazi A, Muller-Hermelink HK, Zettl A, Gobel U, et al. Germ cell tumours of the mediastinum. In: Pleura T, Heart TWD, Brambilla E, MullerHermelink HK, Harris CC, editors. Tumours of the Lung. Lyon: IARC Press; 2004. p. 198-220.

26. Nathan David G M Oski Frank A. MD. Hematology of Infancy and Childhood: W.B. Saunders Company; 1993. 1408 p.

27. Lanzkowsky Jeffrey, Philip LJF. Lanzkowsky's Manual of Pediatric Hematology and Oncology. 2016(6e):Pages 555-68. 
28. Dehner LP. Germ cell tumors of the mediastinum. Semin Diagn Pathol. 1990;7(4):266-84.

29. Horton Z, Schlatter M, Schultz S. Pediatric germ cell tumors. Surg Oncol. 2007;16(3):205-13.

30. Beresford L, Fernandez CV, Cummings E, Sanderson S, Ming-Yu W Giacomantonio M. Mediastinal polyembryoma associated with Klinefelter syndrome. J Pediatr Hematol Oncol. 2003;25(4):321-3.

31. Busch J, Seidel C, Zengerling F. Male Extragonadal germ cell tumors of the adult. Oncol Res Treat. 2016;39(3):140-4.

32. Oosterhuis JW, Stoop H, Honecker F, Looijenga LH. Why human extragonadal germ cell tumours occur in the midline of the body: old concepts, new perspectives. Int J Androl 2007;30(4):256-263; discussion 634.

33. Beck SD, Foster RS, Bihrle R, Donohue JP. Significance of primary tumor size and preorchiectomy serum tumor marker level in predicting pathologic stage at retroperitoneal lymph node dissection in clinical stage a nonseminomatous germ cell tumors. Urology. 2007;69(3):557-9.

34. Perkins GL, Slater ED, Sanders GK, Prichard JG. Serum tumor markers. Am Fam Physician. 2003;68(6):1075-82.

35. Michaelson M Dror MD PKO, MD. Serum tumor markers in testicular germ cell tumors: UpToDate; 2017.

\section{Publisher's Note}

Springer Nature remains neutral with regard to jurisdictional claims in published maps and institutional affiliations.

Ready to submit your research? Choose BMC and benefit from:

- fast, convenient online submission

- thorough peer review by experienced researchers in your field

- rapid publication on acceptance

- support for research data, including large and complex data types

- gold Open Access which fosters wider collaboration and increased citations

- maximum visibility for your research: over $100 \mathrm{M}$ website views per year

At BMC, research is always in progress.

Learn more biomedcentral.com/submissions 